\title{
Developmental hip dysplasia in a 104-year-old patient
}

\author{
Rowan Knulst, Willem-Maarten Bosman, Hugo T C Veger, Ewan D Ritchie
}

Department of Surgery, Rijnland Ziekenhuis, Leiderdorp, The Netherlands

\section{Correspondence to} Dr Ewan D Ritchie, e.ritchie@rijnland.nl

Accepted 6 April 2014

\section{CrossMark}

To cite: Knulst $R$ Bosman W-M, Veger HTC, et al. BMJ Case Rep Published online: [please include Day Month Year] doi:10.1136/bcr-2014204356

\section{DESCRIPTION}

A 104-year-old woman was referred to the emergency ward with a painful pelvis; the result of an unfortunate fall in the middle of the night. The on-call general practitioner visited her for an emergency consultation and suspected a fractured pelvis. On arrival at the hospital a full physical examination was performed, revealing only pelvic tenderness. A plain radiograph showed no evidence of fractures (figure 1). The most remarkable finding was a considerable dislocation of both hips with deformed femoral heads. The acetabuli were both severely dysplastic, with probably neoacetabuli formed at the iliac wing. We transferred the patient to a rehabilitation facility, after a short admission at the hospital. She was unable to regain mobility and eventually passed away due to cachexia.

The spectrum of developmental dysplasia (DDH) of the hip ranges from a mild unstable or subluxatable hip joint to a highly unstable or permanently dislocated hip. It occurs in newborns when the femoral head loses contact with the acetabulum due to 'mechanical' factors. The abnormal contact may lead to a dysplastic acetabulum and sometimes to formation of a neoacetabulum when the joint is

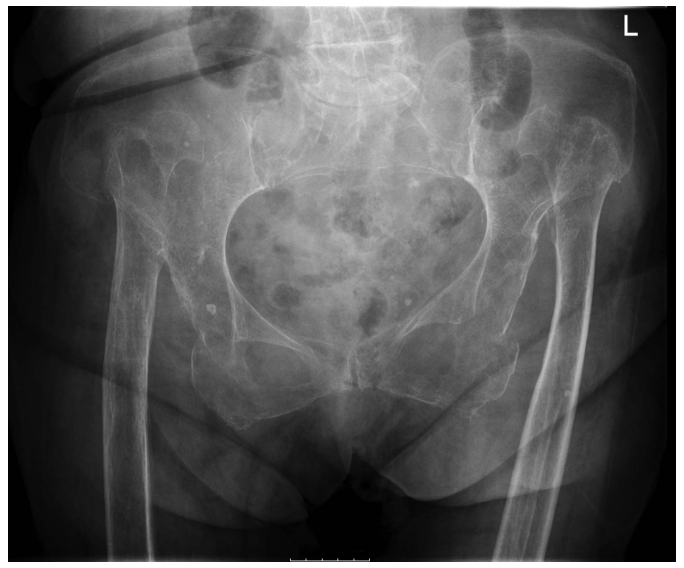

Figure 1 Plain radiograph showing dislocation of both hips with dysplasia of the acetabuli, accompanied by severe deformation of the femoral heads and probably neoacetabuli formed at the iliac wing. not reduced. Treatment today consists of reduction by means of splinting or sometimes surgery at a young age. ${ }^{12} \mathrm{DDH}$ is an important risk factor for developing premature osteoarthritis of the hip, often requiring total hip arthroplasty. ${ }^{3}$ Krych $e t a l^{3}$ describe that satisfactory results of total hip arthroplasty can be obtained even in patients with Crowe type IV DDH; however, often with a greater number of (severe) complications due to difficult anatomy and the need for osteotomy.

Had our patient been diagnosed in her youth, she possibly would have received a tenotomy of the adductor muscles of the thigh, often resulting in limited mobility; a treatment we would conceive as 'brutal' nowadays. ${ }^{4}$ In retrospect, our patient was maybe lucky not to be treated when she was young.

\section{Learning points}

- Developmental hip dysplasia occurs in $4 / 1000$ children.

- Patients with osteoarthritis of the hip often have mild dysplasia as a contributing cause.

- Diagnosis and treatment at a young age can prevent (early) osteoarthritis.

Contributors All authors attributed equally in the treatment of the patient and in writing and reviewing the manuscript.

\section{Competing interests None.}

Patient consent Obtained.

Provenance and peer review Not commissioned; externally peer reviewed.

\section{REFERENCES}

1 Seringe R, Bonnet JC, Katti E. Pathogeny and natural history of congenital dislocation of the hip. Rev Chir Orthop Reparatrice Appar Mot 1990;76:391-402.

2 Dezateux C, Rosendahl K. Developmental dysplasia of the hip. Lancet 2007;369:1541-52.

3 Krych AJ, Howard JL, Trousdale RT, et al. Total hip arthroplasty with shortening subtrochanteric osteotomy in Crowe type-IV development dysplasia. J Bone Joint Surg Am 2009;91:2213-21.

4 Bankart AS. Treatment of congenital dislocation of the hip. BMJ 1913;1:1044-6. 


\section{Images in...}

Copyright 2014 BMJ Publishing Group. All rights reserved. For permission to reuse any of this content visit http://group.bmj.com/group/rights-licensing/permissions.

BMJ Case Report Fellows may re-use this article for personal use and teaching without any further permission.

Become a Fellow of BMJ Case Reports today and you can:

- Submit as many cases as you like

- Enjoy fast sympathetic peer review and rapid publication of accepted articles

- Access all the published articles

- Re-use any of the published material for personal use and teaching without further permission

For information on Institutional Fellowships contact consortiasales@bmjgroup.com

Visit casereports.bmj.com for more articles like this and to become a Fellow 